\title{
Preface: Rift tectonics and syngenetic sedimentation - the Cenozoic Lower Rhine Basin and related structures
}

\author{
A. Schäfer ${ }^{1} \&$ A. Siehl ${ }^{1}$ \\ ${ }^{1}$ Institute of Geology, University of Bonn, Nussallee 8, 53115 Bonn, Germany \\ E-mail: schaefer@uni-bonn.de; siehl@uni-bonn.de
}

Manuscript received: December 2001; accepted: January 2002

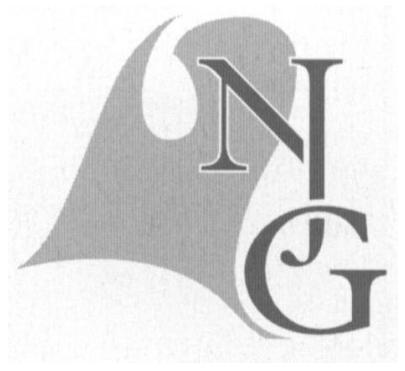

The collection of extended and updated abstracts presented here resulted from a two-day workshop of the Collaborative Research Centre 'Interactions between and Modelling of Continental Geo-Systems' (SFB 350) held on $19^{\text {th }}$ and $20^{\text {th }}$ November, 1999 at the Rheinische Friedrich-Wilhelms-Universität Bonn. This workshop was entitled 'Rift Tectonics and Syngenetic Sedimentation - the Cenozoic Lower Rhine Graben and Related Structures'. Its central topic was devoted to various approaches of understanding the evolution of a young graben structure, with the aim to trace the interaction of tectonics, sedimentation, facies development, burial history, and coherent structural behaviour by integration of geodetic, seismological, gravimetric, sedimentological, paleontological, and climatological data. Analysis and modelling of sedimentary basins, applied to an area of intense intercalation of marine and terrestrial sedimentation, only works, if there are sufficient and consistent stratigraphical data to precise the age control of the deposits.

The papers have different scopes, but overall they show that the RoerValley Graben (= Rur Graben) and the Lower Rhine Basin, parts of a major Cenozoic rift system in the Netherlands and Germany, seem to be in many details - an astonishingly little-known example of a rift-related graben structure forming a sedimentary basin in the very centre of Europe.

The Dutch-German rift system (Fig. 1) transects the Rhenish Shield ('Rheinischer Schild' sensu Cloos, 1939), which comprises the Rhenish Massif ('Rheini- schen Schiefergebirge') in the north and the ancient crystalline massifs of the Black Forest ('Schwarzwald') in the south of Germany and the Vosges ('Vogesen') in neighbouring France. The Upper Rhine Graben bifurcates at the southern margin of the Rhenish Massif NW-ward into the Lower Rhine Basin and the Roer Valley Graben and NE-ward into the Hessen depression, forming a triple junction (Ziegler, 1994). The NW-SE trending faults of the Lower Rhine Basin developed from Early Oligocene times onward, overprinting the pre-existing Paleozoic and Mesozoic structural framework (Vinken, 1991). The Lower Rhine Basin deepens toward the RoerValley Graben in the Netherlands (Verbeek et al., 2002), passing with an offset into the West Netherlands Basin (Cloetingh et al., 2001) and offshore into the Broad Fourteens Basin (Wong et al., 2001).

The southern part of the Dutch-German rift system cuts into the north-western headlands of the Rhenish Massif, forming the $100 \mathrm{~km}$ long and $50 \mathrm{~km}$ wide lowland area, the Lower Rhine Embayment in Germany ('Niederrheinische Bucht'). The rift system consists of a mosaic of north-eastward tilted halfgrabens and horst blocks separated by NW-SE-trending and $\mathrm{SW}$-ward dipping synthetic normal and conjugate NE-ward dipping antithetic faults. Within these grabens, the maximum thickness of the Tertiary and Quaternary siliciclastic basinfill is attained at the respective north-eastern boundary faults, e.g. for the Roer Valley Graben up to $2000 \mathrm{~m}$ along the SW side of the Peel Fault and for the Lower Rhine Basin up to 


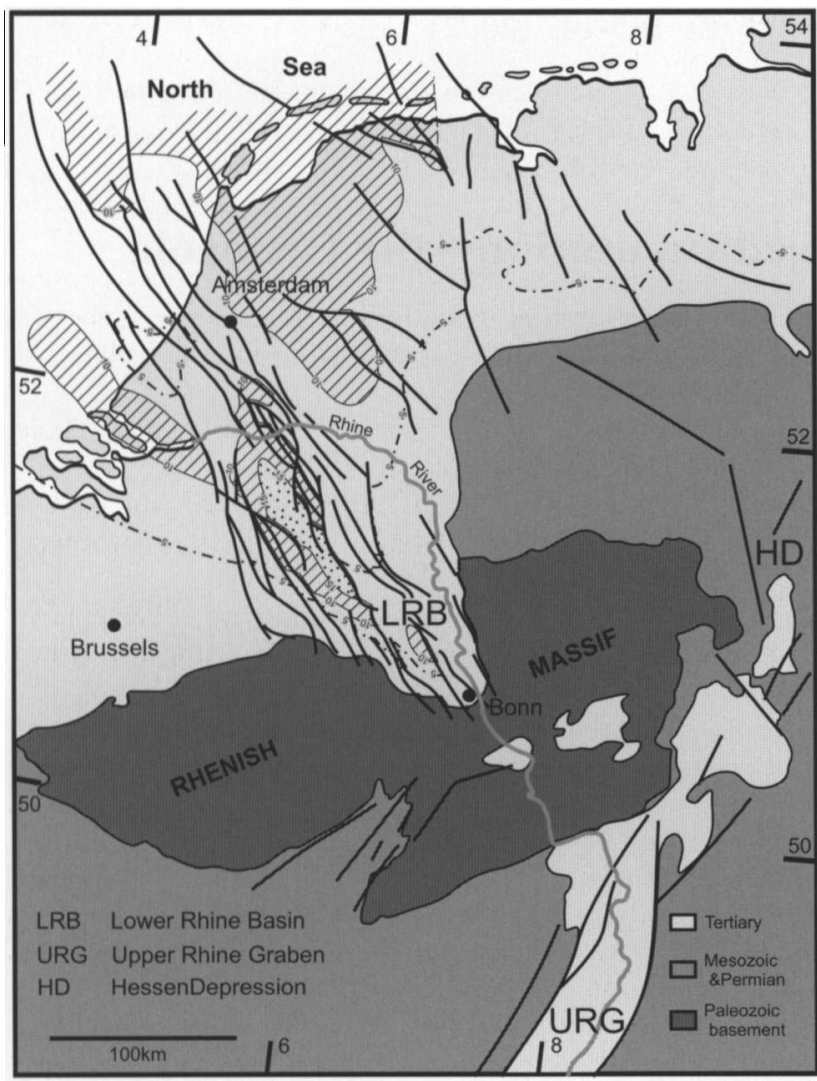

Fig. 1. Structural map verifying the base of the Tertiary in Belgium, the Netherlands, and northern Germany, following Vinken (1991), Zagwijn et al. (1985), and Hager \& Prüfert (1988). The DutchGerman rift system is narrow in the south-east and widens toward the north-west, forming a fan of diverging faults. The overall structure of the rift system might be formed by extension due to sinistral transtensional shear. The Roer Valley Graben and the Lower Rhine Basin could be separated by conjugate shear to form the two individual Dutch and German sub-basins.

$1300 \mathrm{~m}$ along the SW side of the Erft Fault. Rich lignite seams (forming the Main Lignite Seam with a maximum thickness of about $100 \mathrm{~m}$ in the SE part of the Erft Block) have intensely been mined for decades by the local lignite coal industry in open-cast mines in the Lower Rhine Basin. The detailed spatial information on strata and fault geometry available from the mining survey provided the basis for three-dimensional models of backward reconstructions of sedimentation and compaction (Jentzsch \& Siehl, 2002). Moreover, also the design of a kinematic model of a typical faulted domain with the objective to upscale the structural development to a larger area within the rift system could be made (Thomsen \& Siehl, 2002). To facilitate the design and implementation of $3 \mathrm{D} / 4 \mathrm{D}$ geological applications that can hardly be modelled within standard GIS, a component software called GeoToolKit was developed (Breunig et al., 2002).

During the Cenozoic, the embayment area subsided tectonically prior to lignite mining at rates of about $2 \mathrm{~mm} / \mathrm{a}$ along the north-eastern margins of the individual main graben blocks (Quitzow \& Vahlensieck, 1955). Maximum subsidence, including an anthropogenic component due to mine water drainage, amounts to the present rate of at least $30 \mathrm{~mm} / \mathrm{a}$, in some places even more. A horizontal extension in east-west direction of up to $2 \mathrm{~mm} / \mathrm{a}$ is inferred from GPS measurements (Campbell et al., 2002). Regional distribution of recent seismic activity points to a close association with the main normal fault systems, where strike-slip components have been under debate (Ahorner, 1975, 1983, 1997; Klostermann, 1983; Plein et al., 1982; Schreiber \& Rotsch, 1998). Strikeslip components caused by a sinistral transtensional opening of the entire Dutch-German rift system may indeed be indicated by the eastward tilt of its strata and the eastward offset of its southern part, the Lower Rhine Basin.

From the Paleogene onward, the North Sea transgressed onto the lowlands of present-day Belgium, the Netherlands, and Germany. During the initial rift subsidence in Oligocene times - following the rift structures from the north (Kockel, 2002) - the sea onlapped the 'Schiefergebirge' and reworked the debris which was shed by fluvial input from its heights. The ingression of the sea is well documented by coastal marine environments which were deposited under tidal conditions. After the initial rifting during the Early Oligocene, younger basin-fill units apparently prograded northward due to a structural shift of the basin depocentre. The interaction of the Cenozoic North Sea with the coastal plains of the Lower Rhine Basin resulted in well-documented cyclic sedimentation. In the Early Miocene, a coastal plain was formed, that was covered by swamps and forests. Sedimentological analyses from wells and open-cast mines (Klett et al., 2002) and a large amount of biostratigraphical data from within and outside the basin (Moers, 2002; Heumann \& Litt, 2002), yielded information about its sedimentary development and the timing of structural evolution.

When the North Sea retreated again in the Late Miocene and Pliocene, fluvial systems followed the seaward progradation of the coast, and the early precursors of the recent rivers Meuse, Rhine, Sieg, and Wupper frequently cut across the subsiding basin (Van Balen et al., 2002). A gradual decrease in temperature was documented by changes in the floral composition of the plant communities (Utescher et al., 2002). Finally, the Rhenish Massif was uplifted in the Pleistocene to reach its present elevation, and the Rhine River deposited a thick and coarse-grained fluvial outwash-fan towards the North (Boenigk, 2002). In the Rhenish Massif, a staircase of terraces developed by fluvial incision and aggradation as a result of 
the complex interaction of tectonics, sea level, and climatic changes (Meyer \& Stets, 2002).

\section{Acknowledgements}

Our sincere thanks are to the mining company Rheinbraun AG (Köln) who allowed us access to their open cast mines and to benefit from their well logs and structural data. Also, there was gratuitous help from the water supply industry Erftverband e.V. (Bergheim) and the Staatliches Amt für Umweltschutz (Köln/Bonn). Moreover and especially, thanks are due to the Deutsche Forschungsgemeinschaft financing a DFG grant under the auspices of the 'Sonderforschungsbereich 350: Wechselwirkungen kontinentaler Stoffsysteme und ihre Modellierung (Interactions between and Modelling of Continental GeoSystems)', lead by Horst J. Neugebauer (Bonn). Finally, we thank Theo E. Wong (editor: Netherlands Journal of Geosciences / Geologie en Mijnbouw) for encouraging and supporting our editorial tasks.

\section{References}

Ahorner, L., 1975. Present-day stress field and seismotectonic block movements along major fault zones in Central Europe. Tectonophysics 29: 233-249.

Ahorner, L., 1983. Historical seismicity and present-day microearthquake activity of the Rhenish Massif, Central Europe. In: Fuchs, K. et al. (eds): Plateau Uplift. The Rhenish Shield - a case history: Springer Verlag (Heidelberg): 198-221.

Ahorner, L., 1997. Erdbeben in Deutschland 1992. 2 Regionale Berichte. 2.1 Niederrheinische Bucht - Das Erdbeben von Roermond am 13. April 1992. In: Henger, M. \& Leydecker, G. (eds): Berichte der deutschen seismologischen Observatorien mit einem Katalog wichtiger Weltbeben: Bundesanstalt für Geowissenschaften und Rohstoffe (Hannover): $87 \mathrm{pp}$.

Boenigk, W., 2002. The Pleistocene drainage pattern in the Lower Rhine Basin. Netherlands Journal of Geosciences / Geologie en Mijnbouw 81: 201-209 (this issue).

Breunig, M., Balovnev, O., Cremers, A.B. \& Shumilov, S., 2002. Spatial and temporal database support for geologists an example from the Lower Rhine Basin. Netherlands Journal of Geosciences / Geologie en Mijnbouw 81: 251-256 (this issue).

Campbell, J., Kümpel, H.-J., Fabian, M., Fischer, D., Görres, B., Keysers, Ch.J. \& Lehmann, K., 2002. Recent movement pattern of the Lower Rhine Basin from tilt, gravity and GPS data. Netherlands Journal of Geosciences / Geologie en Mijnbouw 81 : 223-230 (this issue).

Cloetingh, S.A.P.L. (ed.), 2001. Environmental Tectonics and Climate: The Netherlands Environmental Earth System Dynamics Initiative (NEESDI). Global and Planetary Change 27: 1-288.

Cloos, H., 1939. Hebung - Spaltung - Vulkanismus; Elemente einer geometrischen Analyse irdischer Großformen. Geologische Rundschau 30: 401-527.

Hager, H. \& Pruefert, J., 1988. Tertiär. In: Hilden, H.D. (ed.): Geologie am Niederrhein. Geologisches Landesamt NordrheinWestfalen (Krefeld): $4^{\text {th }}$ ed.: $32-40$.
Heumann, G. \& Litt, Th., 2002. Stratigraphy and paleoecology of the Late Pliocene and Early Pleistocene in the open-cast mine Hambach (Lower Rhine Basin). Netherlands Journal of Geosciences / Geologie en Mijnbouw 81: 193-199 (this issue).

Jentzsch, T. \& Siehl, A., 2002. Kinematic subsidence modelling of Lower Rhine Basin. Netherlands Journal of Geosciences / Geologie en Mijnbouw 81: 231-239 (this issue).

Klett, M., Eichhorst, F. \& Schäfer, A., 2002. Facies interpretation from well-logs applied to the Tertiary Lower Rhine Graben fill. Netherlands Journal of Geosciences / Geologie en Mijnbouw 81: 167-176 (this issue).

Klostermann, J., 1983. Die Geologie der Krefelder Scholle. Geologisches Jahrbuch A 66: 3-115.

Kockel, F., 2002. Rifting processes in NW-Germany and the German North Sea Sector. Netherlands Journal of Geosciences / Geologie en Mijnbouw 81: 149-158 (this issue).

Meyer, W. \& Stets, J., 2002. Pleistocene to Recent tectonics in the Rhenish Massif (Germany). Netherlands Journal of Geosciences / Geologie en Mijnbouw 81:217-221 (this issue).

Mörs, T., 2002. Biostratigraphy and paleoecology of continental Tertiary vertebrate faunas in the Lower Rhine Embayment (NW-Germany). Netherlands Journal of Geosciences / Geologie en Mijnbouw 81: 177-183 (this issue).

Plein, E., Doerholt, W. \& Greiner, G., 1982. Das Krefelder Gewölbe in der Niederrheinischen Bucht - Teil einer grossen Horizontalverschiebungszone? Fortschritte in der Geologie von Rheinland und Westfalen 30: 15-29.

Quitzow, H.W. \&Vahlensieck, O., 1955. Über pleistozäne Gebirgsbildung und rezente Krustenbewegungen in der Niederrheinischen Bucht. Geologische Rundschau 43: 56-67.

Schreiber, U. \& Rotsch, S., 1998. Cenozoic block rotation according to a conjugate shear system in central Europe - indications from paleomagnetic measurements. Tectonophysics 299: 111-142.

Thomsen, A. \& Siehl, A., 2002. Towards a balanced 3D kinematic model of a faulted domain - the Bergheim open pit mine-. Netherlands Journal of Geosciences / Geologie en Mijnbouw 81: 241-250 (this issue).

Utescher, T., Mosbrugger, V. \& Ashraf, A.R., 2002. Facies and paleogeography of the Tertiary of the Lower Rhine Embayment sedimentary versus climatic control-. Netherlands Journal of Geosciences / Geologie en Mijnbouw 81: 185-191 (this issue).

Van Balen, R.T., Houtgast, R.F., Van der Wateren, F.M. \& Vandenberghe, J., 2002. Neotectonic evolution and sediment budget of the Meuse catchment in the Ardennes and the Roer Valley Rift System. Netherlands Journal of Geosciences / Geologie en Mijnbouw 81: 211-215 (this issue).

Vinken, R. (ed.), 1991. The Northwest European Tertiary Basin. Results of the International Geological Correlation Programme Project No 124. Geologisches Jahrbuch A 100: 508 pp., 267 figs., 3 tabs, 7 maps.

Verbeek, J.W., de Leeuw, C.S., Parker, N. \& Wong, Th.E., 2002. Characterization and correlation of Tertiary seismostratigraphic units in the Roer Valley Graben. Netherlands Journal of Geosciences / Geologie en Mijnbouw 81: 159-166 (this issue).

Wong, Th.E., Parker, N. \& Horst, P., 2001. Tertiary sedimentary development of the Broad Fourteens area, the Netherlands. Netherlands Journal of Geosciences / Geologie en Mijnbouw 80: 85-94.

Zagwijn, W.H., Beets, D.J., van den Berg, M., van Montfrans, H.M. \& van Rooijen, P., 1985. Atlas van Nederland in 20 delen. Deel 13 - Geologie. Stichting Wetenschappelijke Atlas van Nederland. Staatsuitgeverij (s'Gravenhage): $23 \mathrm{pp}$.

Ziegler, P.A., 1994. Cenozoic rift system of western and central Europe: an overview. Geologie en Mijnbouw 73: 99-127. 